\title{
EFFECT OF THE STARTING MICROSTRUCTURE IN THE FORMATION OF AUSTENITE AT THE INTERCRITICAL RANGE IN DUCTILE IRON ALLOYED WITH NICKEL AND COPPER*
}

\author{
Harold D. Machado ${ }^{1}$, Ricardo Aristizabal-Sierra ${ }^{1}$, Carlos Garcia-Mateo ${ }^{2}$, Isaac Toda-Caraballo² \\ ${ }^{1}$ Calle 67 \#53-108, bloque 18, oficina 240, GIPIMME, Department of Materials Engineering, Universidad de \\ Antioquia, Medellin, Colombia \\ ${ }^{2}$ Av/ Gregorio del Amo 8, Materalia Group, National Center for Metallurgical Research (CENIM-CSIC), \\ Madrid-España
}

\begin{abstract}
Intercritical austenitizing is a key step on the production of dual phase austempered ductile iron. Therefore understanding the formation of austenite at the intercritical range should provide critical information for the future development of this family of alloys. In this work, a ductile iron alloyed with copper and nickel (3.4 C, 2.6 Si, $0.9 \mathrm{Ni}, 0.6 \mathrm{Cu}$, wt\%) was studied. The as-cast alloy was submitted to ferritic annealing and normalizing in order to obtain fully ferritic and fully pearlitic microstructures respectively. The effect of microsegregation, initial microstructure (ferrite or pearlite) and nodule count on the formation of austenite in the intercritical range under continuous heating was studied using electron probe micro-analyzer-EPMA-, high-resolution dilatometry, optical microscopy and scanning electron microscope -SEM-. The results showed that silicon, copper and nickel segregate around the graphite nodules and manganese segregates to the last freezing zones, also as nodule count increases the segregation level decreased. Regarding the rate of austenite formation, the results showed that it increases as nodule count increases. Additionally, austenite formation is faster when the starting microstructure is pearlitic and it increases as the pearlite interlaminar spacing decreases. Finally, the results showed that the critical temperatures for austenite formation depend mainly on the starting microstructure (ferrite or pearlite).
\end{abstract}

KEYWORDS: Intercrityically austenitizing, ductile iron microsegregation, austenite formation, intercritically austempered ductile iron, dual phase austempered ductile iron.

\section{INTRODUCTION}

Intercritical austempered ductile iron (IADI) [1-5], also known as dual phase austempered ductile iron [6-8] is an alloy obtained by submitting ductile iron to a thermal cycle that starts with austenitizing at the intercritical range, i.e. austenitizing in the region where graphite nodules, ferrite and austenite coexist, followed by quenching to a temperature between the bainite start (Bs) and martensite start (Ms) and holding long enough for the bainitic transformation to take place. The result is a microstructure of graphite nodules in a matrix of ferrite and ausferrite (bainitic ferrite plus high carbon austenite) [1-13]. The intercritical austenitizing step of the heat treatment has a major effect on the mechanical properties, since it determines the fraction of proeutectoid ferrite and austenite transformation products in the microstructure, thus understanding the formation of austenite at the intercritical range becomes paramount for further development.

Some research about austenite formation can be found for austempered ductile iron where complete austenitization is studied and the holding time is long enough to homogenize the carbon concentration throughout the austenite matrix, and no significant difference is found in the final morphology of the austenite transformation products throughout the matrix [13]. In the same way, there are studies of the simulation of the diffusion of austenite formation during continuous heating and holding for full austenitization. Batra et al. assumed an initially fully ferritic matrix with spherical grains and nodules and proposed a model that allows to calculate the necessary holding time for austenite formation and carbon saturation of the austenite with good agreement with experimental data obtained by microhardness measurements [14]. Lacaze et al. proposed a model for the eutectoid reaction during cooling of Fe-C-Si alloys with spheroidal graphite, taking into account

* This paper is an invited submission to IJMC selected from presentations at the 2nd Carl Loper 2019 Cast Iron Symposium held September 30 to October 1, 2019, in Bilbao, Spain. 
the stable system for the ferritic reaction and the metastable system for the pearlitic reaction. The fraction of transformed austenite was compared with differential thermal analysis (DTA) data and the model described satisfactorily the austenite transformation [15].

Some understanding of ductile iron intercritical austenitizing can be extracted from the study of austenite formation in continuous heating of steels, for example García de Andrés et al. [16] studied using dilatometry the continuous heating curve for ferritic and pearlitic microstructures in steel. They showed the influence of the interlamellar spacing of the pearlite in the rate of austenite formation, based on the studies previously done by Roósz et al. [17]. Regarding ductile iron dilatometry studies, Vazquez-Gomez et al. [18] investigated the austenite formation at different heating rates, they found that the start and end temperatures of the austenitic transformation increase with heating rate. Also, dilatometric studies of ductile iron can be found for the austempering step, but they leave aside intercritical austenitization.

As for the matrix, most research use ductile iron with a ferritic matrix as the starting material, however Lopes [19] studied the influence of the initial matrix on the formation of austenite, starting from ferritic, pearlitic, ausferritic and martensitic microstructures, showing the effect in the final morphology of the austenite transformation products after austempering. Akbarzadeh et al. [20] showed that the nodule count has a marked effect on the final morphology of the bainitic ferrite, since microsegregation within the nodular cast iron changes the transformation phase temperatures and affects carbon diffusion during the transformation. Still, there is limited information on the kinetics of austenite formation in the intercritical range in continuous heating and the influence of the starting microstructure, the nodule count and microsegregation present in the ductile iron, which is the purpose of this paper.

\section{EXPERIMENTAL PROCEDURE}

The chemical composition of the ductile iron used in the present study is given in table 1. The composition was determined by optical emission spectroscopy (OES) using a Bruker Q9 Magellan spectrometer and carbon was determined using a carbon Leco analyzer.

Table 1. Chemical composition of ductile iron (wt\%)

\begin{tabular}{|l|l|l|l|l|l|l|l|l|}
\hline $\mathrm{C}$ & $\mathrm{Si}$ & $\mathrm{Mn}$ & $\mathrm{Ni}$ & $\mathrm{Cu}$ & $\mathrm{P}$ & $\mathrm{S}$ & $\mathrm{Mg}$ & $\mathrm{CE}$ \\
\hline 3.45 & 2.66 & 0.18 & 0.9 & 0.6 & 0.01 & 0.007 & 0.042 & 4.34 \\
\hline
\end{tabular}

Ductile iron returns (50 wt \%), low carbon steel punchings (50 wt\%), low sulfur graphite and ferrosilicon, were used to prepare $50 \mathrm{~kg}$ of ductile iron base alloy in an induction furnace. Magnesium treatment $(2 \mathrm{wt} \%)$ and inoculation $(0.4 \mathrm{wt} \%)$ were performed in an open ladle using a magnesium ferrosilicon alloy $(6.5 \mathrm{wt} \% \mathrm{Mg})$ and ferrosilicon base inoculant (2.7 Ca, 1.5 Al, 2.0 Zr y $0.01 \mathrm{Ce}$, wt\%). Step blocks having $16 \mathrm{~mm}, 32 \mathrm{~mm}$ and 48 $\mathrm{mm}$ wall thicknesses were cast into green sand molds, post-inoculation $(0.1 \mathrm{wt} \%)$ was used before pouring the molds. Specimens of the alloy were heat treated to obtain fully ferritic and fully pearlitic microstructures, the normalizing treatments were designed to obtain samples with two different interlamellar pearlite spacings. These heat-treated materials allowed to evaluate the effect of the starting microstructure, ferrite or pearlite, in the formation of austenite at the intercritical range for a fixed chemistry. The heat treatments were as follows:

- Annealing: Austenitizing at $920^{\circ} \mathrm{C}$ for 2 hours, then slowly cooled into the furnace at a rate of $1.7^{\circ} \mathrm{C} / \mathrm{min}$ to $730^{\circ} \mathrm{C}$ and isothermally held for 5 hours, finally slowly cooled inside the furnace to ambient temperature.

- Normalizing 1 (pearlitic 1): Austenitizing at $920^{\circ} \mathrm{C}$ for 2 hours, then fast cooled to $460^{\circ} \mathrm{C}$ and isothermally held for 1 hour and then air cooling. The samples were quenched and held into a salt bath $\left(50 \mathrm{wt} \% \mathrm{KNO}_{3}+50 \mathrm{wt} \% \mathrm{NaNO}_{2}\right)$.

- Normalizing 2 (pearlitic 2): Austenitizing at $920^{\circ} \mathrm{C}$ for 2 hours, then fast cooled to $500^{\circ} \mathrm{C}$ and held for 1 hour and then air cooling. The samples were quenched and held into a salt bath $\left(50 \mathrm{wt} \% \mathrm{KNO}_{3}+50\right.$ wt $\% \mathrm{NaNO}_{2}$ ). 
Microstructure was examined in samples prepared by standard metallographic techniques using optical microscopy (Nikon, Eclipse MA100 with camera Nikon DS-FI2), and scanning electron microscopy (SEM: JEOL JSM-6490LV). Samples were taken from equivalent points of the castings at each thickness, so they can be compared to each other. Nodule count, nodularity according to ASTM 247 [21] and ASTM 536 [22], interlamellar pearlite spacing [17] and ferrite grain size were determined according to ASTM E112 [23] . Also, electron probe micro-analyzer (EPMA: JEOL Superprobe JXA-8900M) was used to quantify the microsegregation of silicon, manganese, copper and nickel in a $500 \mu \mathrm{m} \times 500 \mu \mathrm{m}$ area. The analysis was performed every $1 \mu \mathrm{m}$, so 250.000 points were collected in each analyzed area. X-ray line profiles between three neighbor graphite nodules were taken and the maximum and minimum molar fractions of each element were calculated. The degree of microsegregation, $\mathrm{K}_{\mathrm{par}}$, was calculated as the average maximum to minimum molar fraction ratio for each element in the X-ray line profiles according to reference [24].

Austenite formation was monitored in Bahr 805A high-resolution dilatometry using cylindrical specimens 10 $\mathrm{mm}$ long and $4 \mathrm{~mm}$ diameter. The analysis was performed in a high-vacuum environment at a heating rate of $0.18^{\circ} \mathrm{C} / \mathrm{s}$. Specimens were heated to $1000^{\circ} \mathrm{C}$. All thicknesses were evaluated for the ferritic and pearlitic 2 alloys, only the $16 \mathrm{~mm}$ thick section was evaluated for the pearlitic 1 microstructure. High resolution dilatometric analysis allowed to obtain the initial austenite formation temperature $\left(\mathrm{T}_{\text {Low }}\right)$, the finalization austenite formation temperature $\left(\mathrm{T}_{\mathrm{High}}\right)$, the apparent end of austenite formation temperature $\left(\mathrm{T}_{\text {End }}\right)$ [25], the austenite formation rate $(\mathrm{R} \gamma)$ and the austenite carbon enrichment rate.

After that, a second set of dilatometric analysis was performed, specimens from the ferritic and pearlitic 2 microstructures were heated at a rate of $0.18^{\circ} \mathrm{C} / \mathrm{s}$ to two temperatures at the intercritical range and then quenched at $100^{\circ} \mathrm{C} / \mathrm{s}$ with helium. The temperatures were selected close and above to the start and close and below to the end of the formation of the austenite in the intercritical range, in order to analyze the differences in the microstructure when the heat treatment starts from ferrite and from pearlite. Samples were prepared by standard metallographic techniques, etched with Nital $1 \%$ and microstructural characterization was made using optical microscopy. The martensite volume fraction after each experimental procedure was determined by systematic point counting in at least 10 frames according to ASTM E562 [26].

\section{6 \\ Starting microstructure}

RESULTS AND DISCUSSION

Nodularity was above $90 \%$ for all section thicknesses and, as expected, nodule count increases as section thickness in the step block decreases, which is attributed to the higher cooling rate of the thinner sections. Ferrite grain size was around $40 \mu \mathrm{m}$ for all conditions, there is no variation in the ferritic grain size according to thickness, because in this case the grain size depends on the annealing conditions and not on the cooling rate. Interlamellar pearlite spacing had two levels, pearlite 1 and pearlite 2, to evaluate the influence of this parameter in the austenite formation at the intercritical range. Carbides were not observed in the microstructure. Table 2 lists the results of the characterization of the starting microstructures. Figure 1 shows representative micrographs of unetched samples, figure 2 shows representative micrographs of samples etched with Nital 1\% 125 after annealing and normalizing.

Table 2. Results of the starting microstructure characterization.

\begin{tabular}{|l|l|l|l|l|l|}
\hline \multirow{2}{*}{$\begin{array}{l}\text { Thickness } \\
(\mathrm{mm})\end{array}$} & \multirow{2}{*}{ \%Nodularity } & $\begin{array}{l}\text { Nodule count } \\
\left(\text { Nodules } / \mathrm{mm}^{2}\right)\end{array}$ & $\begin{array}{l}\text { Ferrite grain size } \\
(\mu \mathrm{m})\end{array}$ & \multicolumn{3}{|l|}{ Pearlite interlamellar spacing $(\mu \mathrm{m})$} \\
& & $\begin{array}{l}\text { Normalizing } 1 \\
\left(460{ }^{\circ} \mathrm{C}\right)\end{array}$ & $\begin{array}{l}\text { Normalizing } 2 \\
\left(500^{\circ} \mathrm{C}\right)\end{array}$ \\
\hline 16 & \multirow{3}{*}{$>90$} & 295 & $40.6 \pm 2.0$ & & \\
& 280 & $40.7 \pm 3.0$ & $0.218 \pm 0.018$ & $0.326 \pm 0.010$ \\
& 250 & $41.0 \pm 2.0$ & & \\
\hline 48 & & &
\end{tabular}



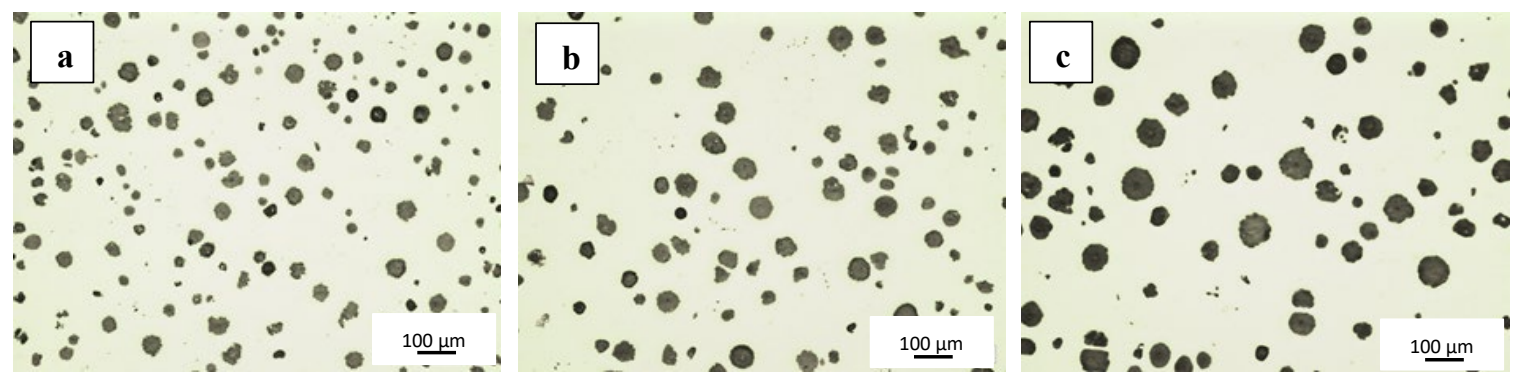

Fig 1. Representative micrographs of unetched samples of thickness: (a) $16 \mathrm{~mm}$, (b) $32 \mathrm{~mm}$, (c) $48 \mathrm{~mm}$.

Micrographs were taken at $100 \mathrm{X}$ and show an area of $0.5 \mathrm{~mm}^{2}$.
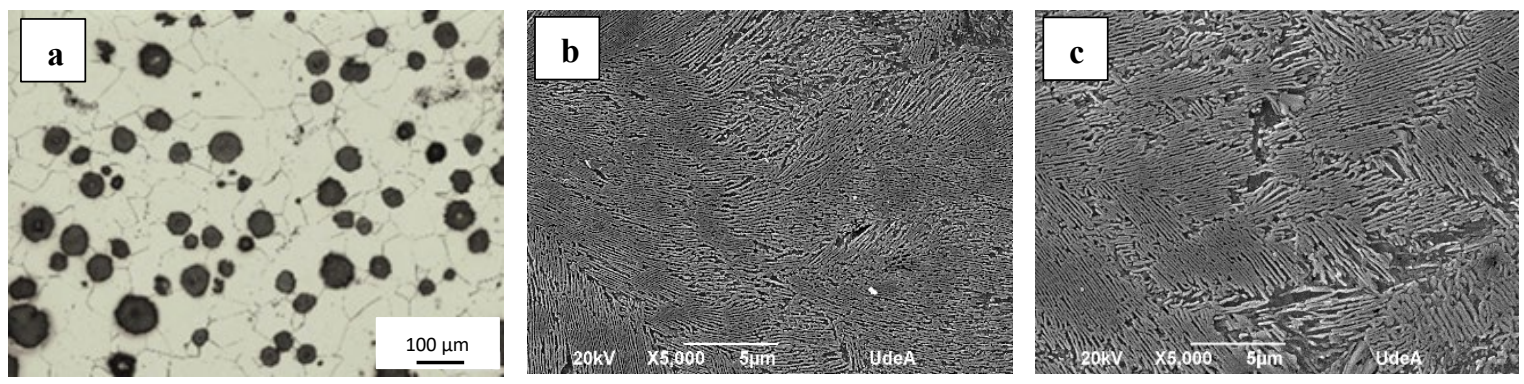

Fig 2. Representative micrographs of samples etched with Nital $1 \%$. (a) Optical microscope, ferritic microstructure, taken at 100X (b) secondary electrons - SEM, pearlitic 1 microstructure from normalizing at $460^{\circ} \mathrm{C}$, (c) Secondary electrons - SEM pearlitic 2 microstructure from normalizing at $500^{\circ} \mathrm{C}$.

\section{Microsegregation}

In order to quantify microsegregation, compositional maps of $\mathrm{Si}, \mathrm{Mn}, \mathrm{Ni}$, and $\mathrm{Cu}$ were acquired using EPMA. The analyses were performed in samples $16 \mathrm{~mm}$ and $48 \mathrm{~mm}$ thick. Figure 3 shows compositional maps for the samples with a ferritic microstructure. The results for pearlitic microstructures did not show any significant difference compared to the ferritic ones, which is attributed to the fact that the heat treatments (annealing and normalizing) temperatures were not high enough to allow the diffusion of substitutional elements, so the results reflect the microsegregation of the as-cast microstructure. Figure 4 shows representative compositional profiles between to neighbour graphite nodules. As it can be seen in figures 3 and 4, copper, nickel and silicon concentration are higher close to the graphite nodules and their concentration decreases towards the last freezing zones, which indicates a negative segregation. Manganese in the other hand showed positive segregation, meaning that the concentration is lower close to the graphite nodules and increased towards the last freezing zones. These results are similar to the ones reported in previous researches like Nastac et al. that proposed a model to calculate the distribution of $\mathrm{Mn}, \mathrm{Mo}, \mathrm{Cu}$, and $\mathrm{Si}$ in ductile iron taking into account the diffusion in the liquid and solid state [27].

Mn Map 1

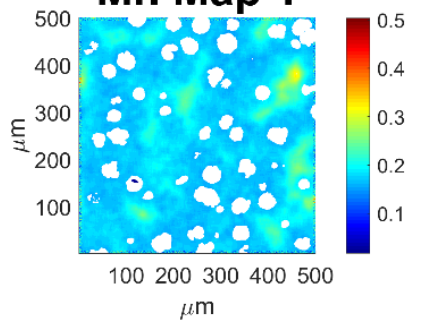

Cu Map 1

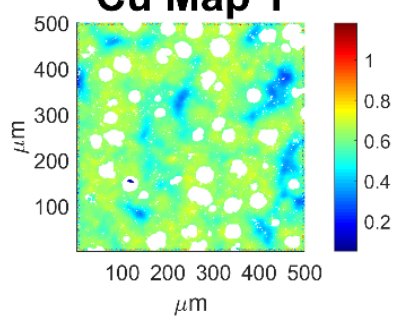

Ni Map 1

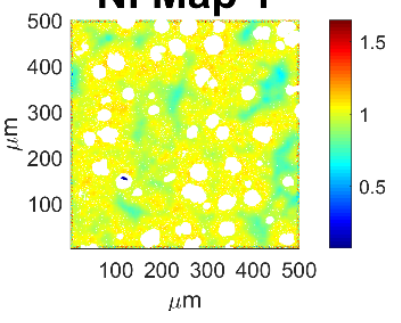

Si Map 1

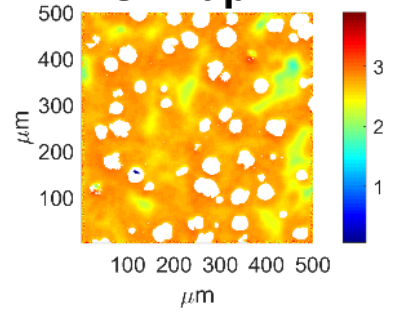



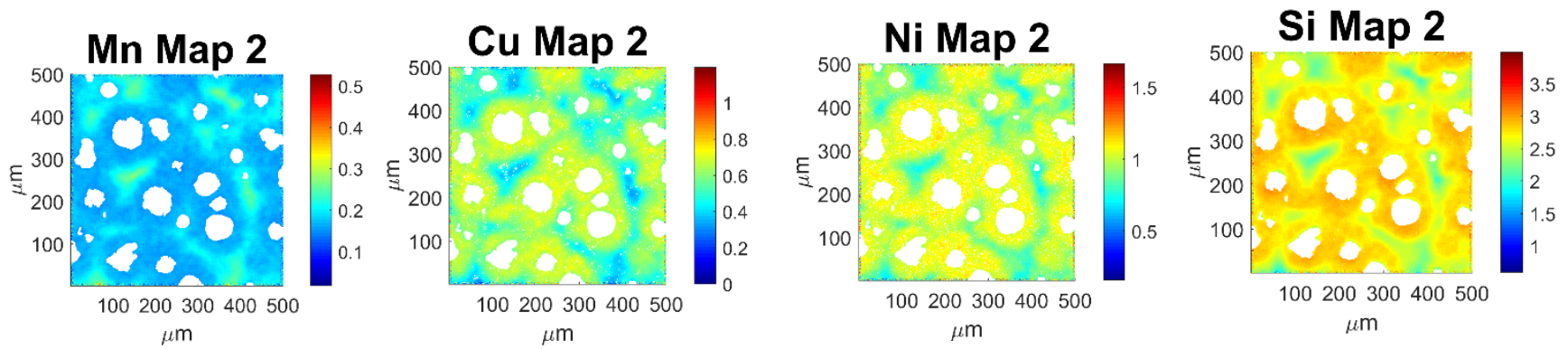

Fig 3. Compositional maps acquired by EPMA in ferritic samples. Map 1 is for the $16 \mathrm{~mm}$ thick section and Map 2 is for the $48 \mathrm{~mm}$ thick section. The scales at the right side of the maps indicate concentration in $\mathrm{wt} \%$.
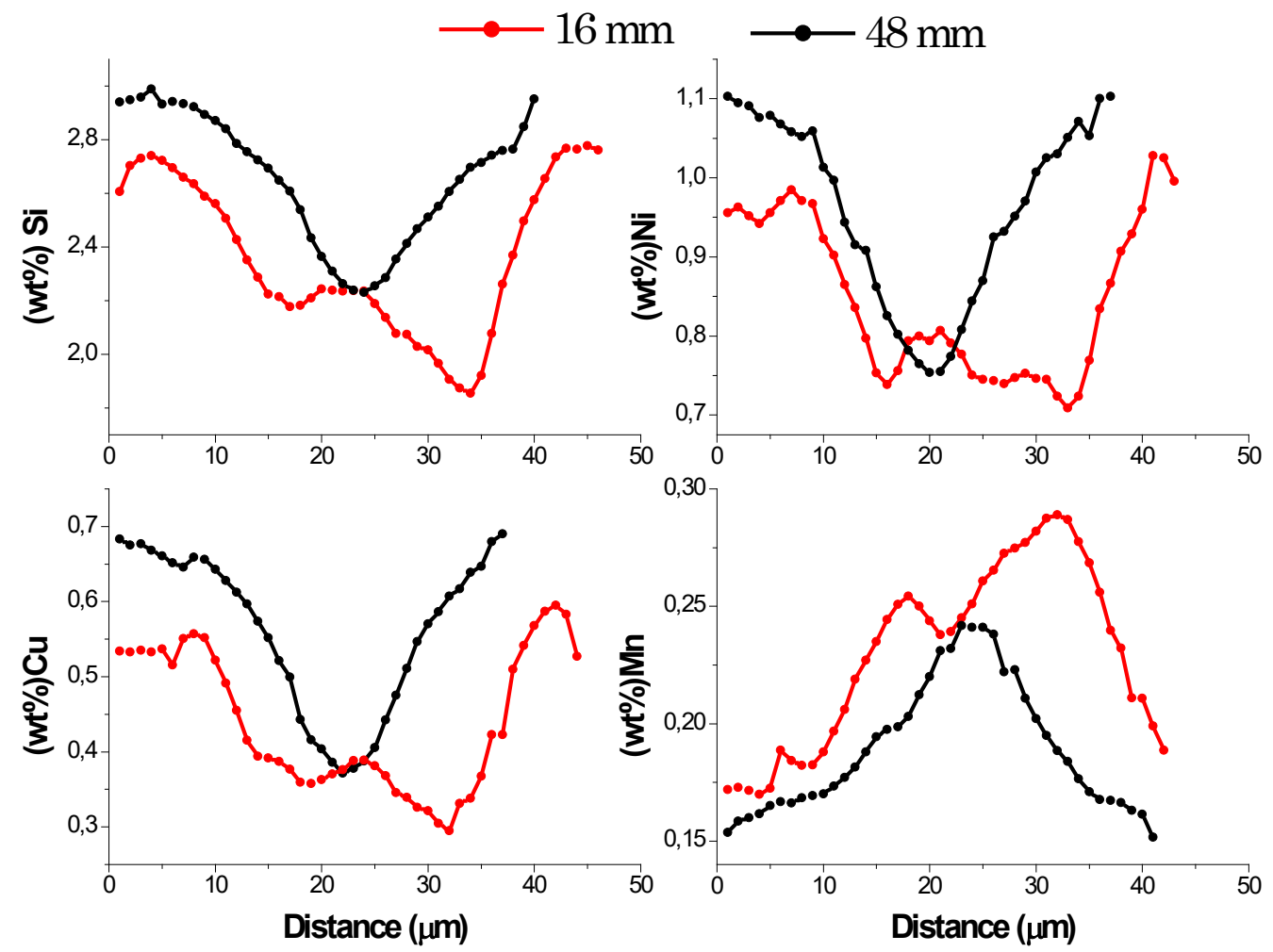

145

Fig 4. Representative concentration profile of $\mathrm{Si}, \mathrm{Mn}, \mathrm{Ni}$, and $\mathrm{Cu}$ between two neighbor graphite nodules.

Further analysis of the data obtained by EPMA was performed by calculating the degree of microsegregation, $\mathrm{K}_{\mathrm{par}}$, for each element as described in the experimental procedure according to reference [24]. A $\mathrm{K}_{\mathrm{par}}=1$ will mean no segregation of the element, also a higher $K_{\text {par }}$ value would mean a greater microsegregation, so $K_{p a r}$ parameter is a way to clarify the differences in microsegregation according to nodule count for the analyzed chemical elements. Table 3 shows the maximum and minimum molar fraction for each element for the $16 \mathrm{~mm}$ and $48 \mathrm{~mm}$ sections and for the ferritic and pearlitic samples and lists the results of the calculation of $\mathrm{K}_{\mathrm{par}}$. As explained before the data reported are the average of analyzing the chemistry profiles between three neighbor graphite nodules in each sample. The results show that $\mathrm{K}_{\text {par }}$ increases as section thickness increases for all chemical elements under analysis, which clearly indicates that there is more microsegregation as nodule count decreases. Similar results have been reported by Lin et al. that found that increasing the solidification module increases segregation [28]. Also, silicon and manganese showed the lowest and highest variation respectively in $\mathrm{K}_{\mathrm{par}}$ as section thickness increases, which means that silicon is the element whose microsegregation is the 
least affected and manganese the most affected by nodule count. The importance of analyzing microsegregation comes from the fact that local chemistry composition affects the austenite start and austenite finish temperatures, thus when the austenization is performed at the intercritical range some microstructural regions will form austenite and some will not according to local chemistry.

Table 3. Minimum and maximum concentration of $\mathrm{Si}, \mathrm{Ni}, \mathrm{Cu}$ and, $\mathrm{Mn}$ and $\mathrm{K}_{\mathrm{par}}$.

\begin{tabular}{|c|c|c|c|c|c|c|c|}
\hline \multirow{3}{*}{ Element } & \multirow{3}{*}{$\begin{array}{l}\text { Thickness, } \\
\mathrm{mm}\end{array}$} & \multicolumn{3}{|l|}{ Ferritic } & \multicolumn{3}{|l|}{ Pearlitic 2} \\
\hline & & \multicolumn{2}{|c|}{ Molar fraction $(\chi)$} & \multirow{2}{*}{$\mathrm{K}_{\mathrm{par}}$} & \multicolumn{2}{|c|}{ Molar fraction $(\chi)$} & \multirow[b]{2}{*}{$\mathrm{K}_{\mathrm{par}}$} \\
\hline & & Minimum & Maximum & & Minimum & Maximum & \\
\hline \multirow{2}{*}{$\mathrm{Si}$} & 16 & 0.0387 & 0.0489 & $1.31 \pm 0.02$ & 0.0401 & 0.0467 & $1.34 \pm 0.03$ \\
\hline & 48 & 0.0294 & 0.0500 & $1.50 \pm 0.08$ & 0.0327 & 0.0512 & $1.78 \pm 0.05$ \\
\hline \multirow{2}{*}{$\mathrm{Ni}$} & 16 & 0.0055 & 0.0086 & $1.50 \pm 0.09$ & 0.0065 & 0.0074 & $1.50 \pm 0.04$ \\
\hline & 48 & 0.0039 & 0.0088 & $1.98 \pm 0.14$ & 0.0041 & 0.0089 & $1.67 \pm 0.02$ \\
\hline \multirow{2}{*}{$\mathrm{Cu}$} & 16 & 0.0034 & 0.0052 & $1.56 \pm 0.08$ & 0.0036 & 0.0047 & $1.65 \pm 0.04$ \\
\hline & 48 & 0.0024 & 0.0068 & $1.95 \pm 0.11$ & 0.0024 & 0.0065 & $2.63 \pm 0.09$ \\
\hline \multirow{2}{*}{$\mathrm{Mn}$} & 16 & 0.0014 & 0.0016 & $1.63 \pm 0.13$ & 0.0012 & 0.0020 & $1.79 \pm 0.09$ \\
\hline & 48 & 0.0013 & 0.0028 & $2.07 \pm 0.14$ & 0.0014 & 0.0028 & $2.24 \pm 0.11$ \\
\hline
\end{tabular}

Analysis of the austenite formation in the intercritical range

The determination of the critical temperatures from the dilatometric results was as following description: $\mathrm{T}_{\text {Low }}$ corresponds to the first inflection in the dilatometric curve as the temperature raises, $\mathrm{T}_{\text {High }}$ is the second inflection and $\mathrm{T}_{\text {end }}$ is the third inflection. The inflections were determined by looking at the first derivative of the dilatometric curves. Figures 5 shows representative dilatometric curves of the conditions that were evaluated, the dotted vertical lines are a reference of the approximate critical temperatures, the exact values are listed in table 4 . Figure $5 \mathrm{a}$ corresponds to the results for ferritic microstructures and figure $5 \mathrm{~b}$ display the results for pearlitic microstructures.

$\mathrm{T}_{\text {low }}$ temperature indicates the start of the formation of austenite and the beginning of the intercritical range. The ferritic samples show a lower contraction than the pearlitic because the volumetric change associated with the ferrite to austenite transformation produces an expansion as consequence of the larger lattice parameter of the later compared to the former. In the other hand, the volumetric change associated with the pearlite to austenite transformation involves a contraction linked to the dissolution of carbides in the pearlite [16]. As the temperature raises continuously a second inflection, $\mathrm{T}_{\mathrm{High}}$, is reached which indicates the temperature at which the transformation will end under very slow heating rates closer to stable equilibrium for the ferritic matrix and metastable equilibrium for the pearlitic matrix. Finally, $\mathrm{T}_{\mathrm{End}}$ corresponds to the temperature where the formation of austenite has been completed and indicates the end of the intercritical range under the conditions of the measurement. It is important to note that $\mathrm{T}_{\text {End }}$ depends strongly on heating rate, a higher heating rate will give higher $T_{\text {End }}$ [18]. The results showed that $T_{\text {Low }}, T_{\text {High }}$ and $T_{\text {End }}$ in the ferritic microstructures occurs at higher temperatures than in the pearlitic microstructures, the differences in $T_{\text {Low }}$ are because the nucleation of austenite occurs much faster in pearlite, where nucleation occurs preferentially at the intercepts between the cementite and the edges of the pearlite colonies, and then grows by the diffusion of carbon from the cementite to the austenite [29]. Also, as established by Gervel et al. the ferrite to austenite transformation proceeds according to the stable system, whereas the pearlite to austenite transformation follows the metastable system. A calculation of the stable and metastable eutectoid temperatures using equations from Gervel et al. [30] gives for the ferritic microstructures a $\mathrm{T}_{\text {Low }}$ of $796^{\circ} \mathrm{C}$ and for the pearlitic microstructures a $\mathrm{T}_{\text {Low }}$ of $780{ }^{\circ} \mathrm{C}$, which agree well with the results from the dilatometric experiments. 

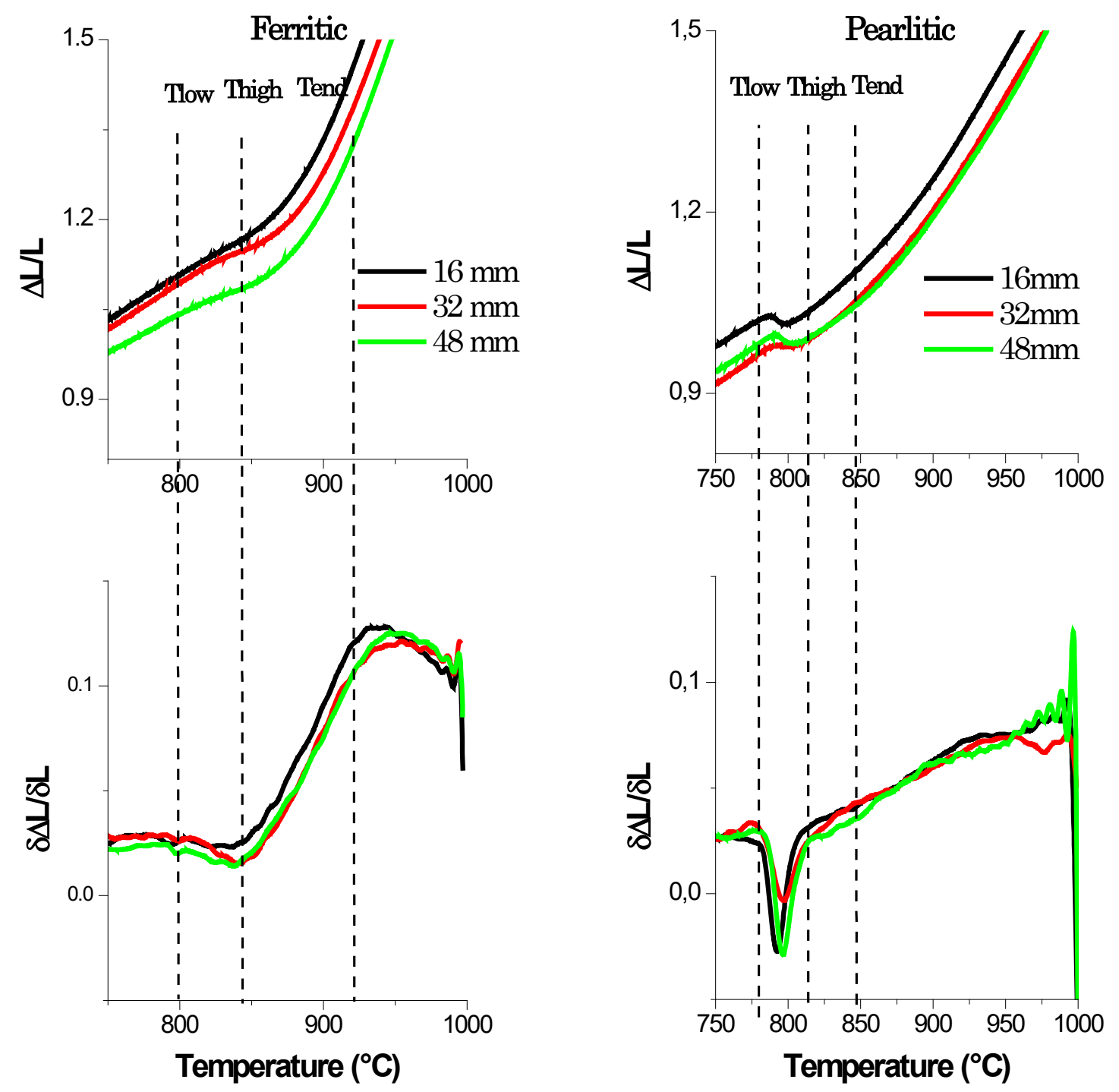

Fig 5. Dilatometric curves for samples with different thicknesses. a) Ferritic matrices, b) pearlitic 2 matrices.

Regarding $\mathrm{T}_{\mathrm{High}}$ and $\mathrm{T}_{\mathrm{End}}$, the differences between microstructures are mainly due to the diffusion of carbon, in the ferritic samples carbon is only available from the graphite nodules while in the pearlitic samples carbon is available from the pearlite and the graphite nodules, moreover the diffusion path for carbon from the pearlite decomposition is ten times smaller than the diffusion path for carbon from the graphite nodules, so carbon diffusion will take less time in the pearlitic microstructures. As pointed out earlier, $\mathrm{T}_{\mathrm{High}}$ is the temperature at which transformation would occur at very slow heating rates, closer to stable equilibrium for the ferritic microstructures and metastable equilibrium for pearlitic microstructures. Then at a very slow heating conditions $\mathrm{T}_{\text {High }}$ and $\mathrm{T}_{\mathrm{End}}$ should be the same. In the present case the differences arise from: 1) microsegregation of the alloying elements, then the austenitization temperature will change locally in the matrix, 2) carbon is always available from the graphite nodules and austenite carbon concentration in equilibrium changes as the temperature raises in continuous heating conditions and 3) the heating rate is not slow enough to allow either stable or metastable equilibrium conditions [29,31].

Concerning to the rate of austenite formation, $\mathrm{R} \gamma$, it is also slightly higher for the pearlitic than for the ferritic microstructures, which can be explained by the same reasons: more carbon is available and there are more 206 austenite nucleation sites in the pearlite. However, the rate of carbon recovery in austenite is lower for the 
pearlitic microstructures, which is because the transformation happens at lower temperatures, then carbon diffusion is slower.

Referring to the influence of the interlamellar pearlite spacing, table 4 shows that critical temperatures are slightly lower and $\mathrm{R} \gamma$ is higher when the interlamellar pearlite spacing is smaller (pearlite 1). Hillert et al. $[25,32]$ established that the process of forming austenite from pearlite is controlled by the diffusion of carbon and consider that the effective distance of diffusion is approximately equal to the interlamellar spacing of pearlite. Therefore, it can be said that the pearlite with smaller interlamellar spacing will transform faster and in a lower temperature range, which agrees with the experimental data from the dilatometry. Also, a finer pearlite will provide more nucleation sites for the formation of austenite increasing $\mathrm{R} \gamma$.

It can be recalled that according to table 2, the heat treatments performed before the dilatometric analysis provided the same ferritic grain size (around $40 \mu \mathrm{m}$ ) for all casting section thickness that were annealed. The interlamellar pearlite 2 spacing of the normalized samples was also the same regardless casting section thickness. Thus any difference in $\mathrm{R} \gamma$ arises from the initial microstructure, ferrite or pearlite, or the nodule count which as explained before is directly linked to microsegregation. The effect of the matrix was already mentioned in the last paragraphs. Regarding the effect of the nodule count, the data in table 4 shows that $\mathrm{R} \gamma$ increases as nodule count increases for both, ferritic and pearlitic microstructures. The data also shows that the effect is slightly larger for the ferritic microstructures, which may be associated to the fact that the only source of carbon in the ferritic samples are the graphite nodules. The effect of nodule count on $\mathrm{R} \gamma$ can be linked to a smaller carbon diffusion path, i.e. the graphite nodules are closer as nodule count increases.

Finally, the rate of carbon recovery was calculated as the rate of austenite dilatation after $\mathrm{T}_{\text {End, }}$, which occurs due to the increasing carbon concentration in the austenite. As can be seen in table 4, the rate of carbon does not change considerably as function of nodule count (casting thickness), but it does change according to the starting microstructure, having higher values for ferritic than for pearlitic microstructures. This results indicate a lower carbon concentration in the austenite coming from a ferritic microstructure at the end of the transformation, thus there is a greater need of carbon gain until saturation when the system starts from a ferritic matrix [33].

\begin{tabular}{|l|c|c|c|c|c|c|}
\hline Table 4. Dilatometry results for ferritic and pearlitic microstructures. \\
\hline Matrix & $\begin{array}{c}\text { Thickness } \\
(\mathrm{mm})\end{array}$ & $\begin{array}{c}\mathrm{T}_{\text {Low }} \\
\left({ }^{\circ} \mathrm{C}\right)\end{array}$ & $\begin{array}{c}\mathrm{T}_{\text {High }} \\
\left({ }^{\circ} \mathrm{C}\right)\end{array}$ & $\begin{array}{c}\mathrm{T}_{\text {End }} \\
\left({ }^{\circ} \mathrm{C}\right)\end{array}$ & $\begin{array}{c}\text { Rate of } \\
\text { transformation }\left({ }^{\circ} \mathrm{C}^{-1}\right)\end{array}$ & $\begin{array}{c}\text { Rate of Carbon } \\
\text { recovery }\left({ }^{\circ} \mathrm{C}^{-1}\right)\end{array}$ \\
\hline \multirow{3}{*}{ Ferritic } & 16 & 797 & 838 & 927 & $2.45 \mathrm{E}-4$ & $1.18 \mathrm{E}-3$ \\
\cline { 2 - 7 } & 32 & 805 & 843 & 931 & $2.13 \mathrm{E}-4$ & $1.13 \mathrm{E}-3$ \\
\cline { 2 - 7 } & 48 & 801 & 840 & 933 & $1.75 \mathrm{E}-4$ & $1.13 \mathrm{E}-3$ \\
\hline Pearlitic 2 & 16 & 780 & 802 & 845 & $2.66 \mathrm{E}-4$ & $6.82 \mathrm{E}-4$ \\
\cline { 2 - 7 } & 32 & 792 & 797 & 848 & $2.43 \mathrm{E}-4$ & $6.39 \mathrm{E}-4$ \\
\cline { 2 - 7 } & 48 & 788 & 803 & 848 & $2.14 \mathrm{E}-4$ & $6.68 \mathrm{E}-4$ \\
\hline Pearlitic 1 & 16 & 779 & 796 & 840 & $1.05 \mathrm{E}-3$ & $7.07 \mathrm{E}-4$ \\
\hline
\end{tabular}

\section{Microstructural analysis of samples quenched from the intercritical range}

In order to check the microstructural changes during austenite formation as a function of temperature in the intercritical range, some additional dilatometry tests were made as described in section 2 . When starting from the ferritic microstructures intercritical austenitizing done at $800^{\circ} \mathrm{C}$ followed by quenching (figure $6 \mathrm{a}$ ) showed graphite nodules in a ferritic matrix with some martensite $\left(\alpha^{\prime}\right)$ located between the primary graphite nodules, which indicates that the high temperature austenite starts to form at the last freezing zones. The determination of the amount of martensite by point counting gave $4 \mathrm{vol} \%$ of martensite (or high temperature austenite), so the temperature is close to $T_{\text {Low }}$. Figure $6 \mathrm{~b}$ shows the microstructure of a ferritic sample intercritically austenitized at $880^{\circ} \mathrm{C}$ and then quenched, the matrix has $78 \mathrm{vol} \%$ martensite (austenite at high temperature). The remaining ferrite is dispersed in the martensitic matrix as allotriomorphic ferrite. 

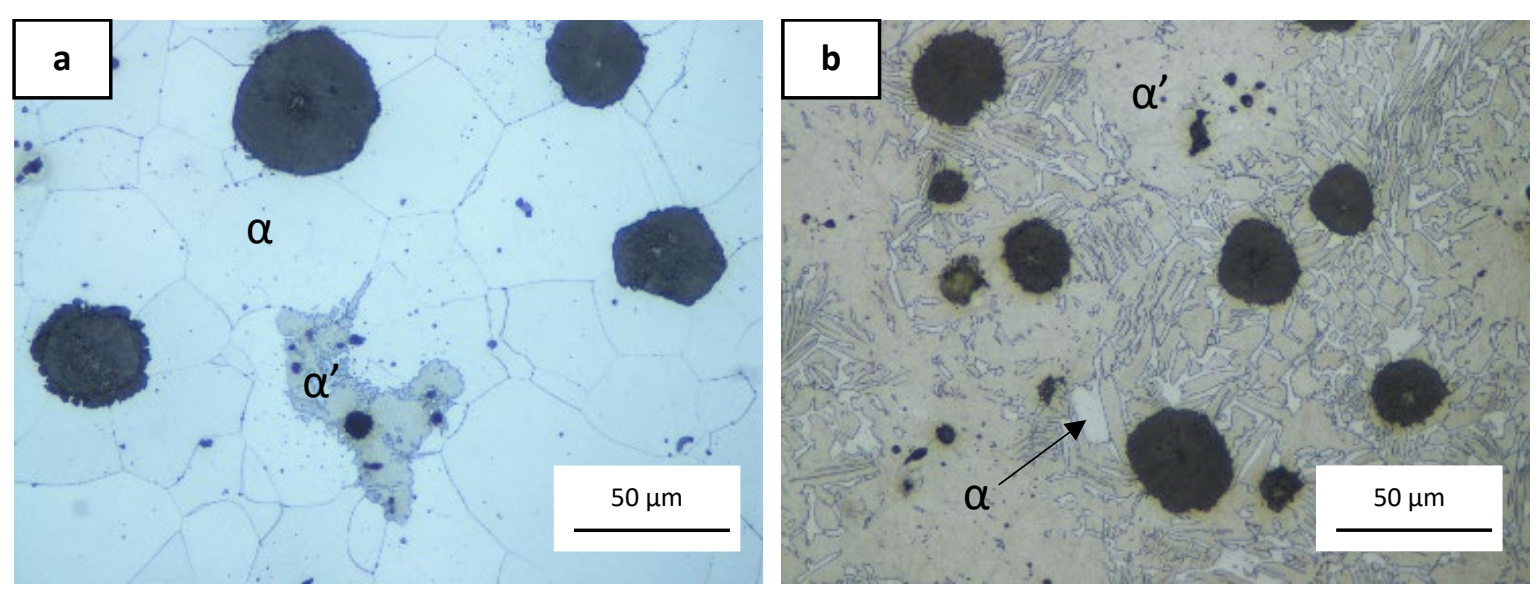

Fig 6. Representative micrographs of ferritic samples intercritically austenitized at: (a) $800^{\circ} \mathrm{C}$ and (b) $880^{\circ} \mathrm{C}$.

On the other hand, the pearlitic microstructures austenitized at $790^{\circ} \mathrm{C}$ followed by quenching (Figure 7a) showed graphite nodules in a matrix containing martensite (high temperature austenite), ferrite and undissolved pearlite, which indicates that the temperature was close to $\mathrm{T}_{\text {Low }}$. Martensite is found preferentially at the last freezing zones, whereas ferrite is in the areas close to the graphite nodules. At $840^{\circ} \mathrm{C}$ (Figure $7 \mathrm{~b}$ ), the remaining ferrite is allotriomorphic and located close to the graphite nodules. Martensite (high temperature austenite) percent determined by point counting is $95 \mathrm{vol} \%$, which indicates that the temperature was close to $\mathrm{T}_{\text {End. }}$. It must be remembered that the experiments were done under continuous heating conditions without holding at the austenitizing temperature.
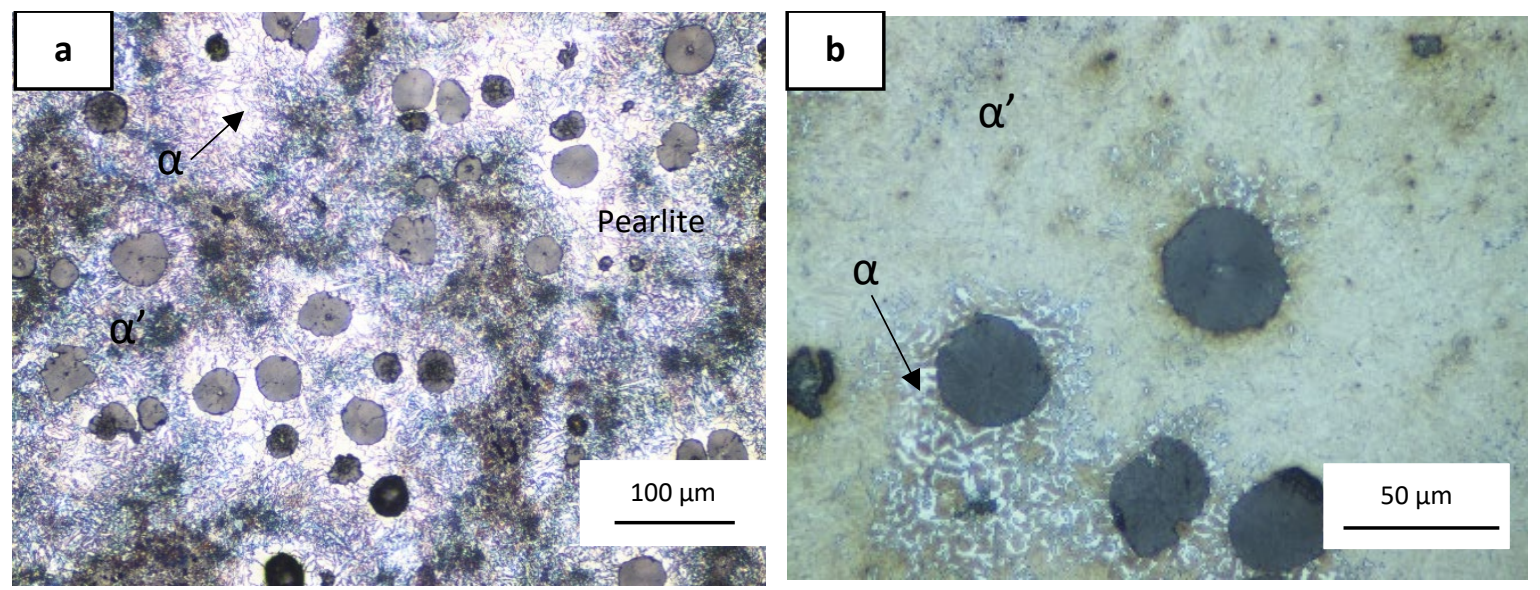

Fig 7. Representative micrographs of pearlitic samples intercritically austenitized at: a) $790{ }^{\circ} \mathrm{C}$ ) and b) $840^{\circ} \mathrm{C}$.

\section{CONCLUSIONS}

1. Microsegregation decreases as nodule count increases in ductile iron. Lower microsegregation provides greater homogeneity of alloying elements in the microstructure with a direct involvement in the austenite formation, since microsegregation changes critical temperatures locally in the matrix, also local chemistry variations in the high temperature austenite can affect the morphology of austenite products.

2. The critical temperatures of formation of austenite under continuous heating depend mainly on the starting microstructure, these temperatures are higher for a ferritic microstructure, which is caused by the lower amount of carbon in the matrix and the lower amount of nucleation sites compare to the pearlitic microstructures. 
3. Nodule count have a minor influence on the critical temperatures of austenite formation, however it affects the rate of austenite formation, higher nodule count gives a higher austenite formation rate in continuous heating conditions.

\section{AKNOWLEDGMENTS}

The authors want to acknowledge COLCIENCIAS (Call 727), CODI (PRG 2017-16229) and CENIM (National Center for Metallurgical Research-Madrid-Spain). I. Toda-Caraballo is grateful for financial support of the fellowship 2016-T2/IND-1693, from the Programme Atracción de talento investigador (Consejería de Educación, Juventud y Deporte, Comunidad de Madrid).

\section{REFERENCES}

[1] R.E. Aristizabal, A.P. Druschitz, E. Druschitz, R. Bragg, C.R. Hubbard, T.R. Watkins, M. Ostrander, "Intercritically Austempered Ductile Iron”, AFS Transactions, 119, 407-413, 2011.

[2] R.E. Aristizabal, Intercritical Heat Treatments in Ductile Iron and Steels, in Material Science and Engineering, PhD Dissertation 2012, University of Alabama, Birmingham.

[3] R.E. Aristizabal, R. Foley, A. Druschitz, Intercritically austenitized quenched and tempered ductile iron, International Journal of Metalcasting, 6 (4), 7-14, 2012.

[4] A.P. Druschitz, R.E Aristizabal, E. Druschitz, C.R. Hubbard, In Situ Studies of Intercritically Austempered Ductile Iron Using Neutron Diffraction. Metallurgical and Materials and Transactions A, 43 (5), 1468-1476, 2012.

[5] A.P. Druschitz, R.E. Aristizabal, E. Druschitz, C. Hubbard, Neutron diffraction studies of intercritically austempered ductile irons. SAE International Journal of Materials and Manufacturing, 4 (1), 111$118,2011$.

[6] A.D. Basso, R.A. Martinez, J. Sikora. Influence of austenitizing temperatures on mi-crostructure and properties of dual phase ADI. Materials Science and Technology, 23, 1321-26, 2007.

[7] A.D. Basso, M. Caldera, M. Chapetti, J. Sikora. Mechanical properties of dual phase austempered ductile iron. ISIJ International, 50, 302-06, 2010.

[8] A. Basso, J. Sikora, Review on production processes and mechanical properties of dual phase austempered ductile iron, International Journal of Metalcasting, 6, 7-14, 2012.

[9] V. Kilicli, M. Erdogan. Tensile properties of partially austenitised and austempered ductile irons with dual matrix structures. Materials Science \& Technology, 22, 919-28, 2006.

[10] M. Erdogan, V. Kilicli, B. Demir. The influence of austenite dispersion on phase transformation during the austempering of ductile cast iron having a dual phase ma-trix structure. International Journal of Materials Research, 99, 751-60, 2008.

[11] V. Kilicli, M. Erdogan. The strain-hardening behavior of partially austenitized and the austempered ductile irons with dual matrix structures. Journal of Materials En-gineering and Performance. 17, 240-49, 2008.

[12] V. Kilicli, M. Erdogan. The nature of the tensile fracture in austempered ductile iron with dual matrix microstructure. Journal of Materials Engineering and Performance, 19, 142-49, 2010.

[13] S. D. Z. Ławrynowicz, Bainitic transformation during Austempering of Ductile Cast Iron, Indian Journal, V (IV), 71-76, 2016.

[14] U. Batra, S. Ray, S.R. Prabhakar, Mathematical Model for Austenitization Kinetics of Ductile Iron, ASM International, 14, 574-581, 2005. 
[15] J. Lacaze, L. Matriaux, Modelling of the Eutectoid Reaction Fe-C-Si Alloys, ISIJ International, 38 (7), 714-722, 1998.

[16] C. García De Andrés, F. G. Caballero, C. Capdevila, H. K. D. H. Bhadeshia, Modelling of kinetics and dilatometric behavior of non-isothermal pearlite-to-austenite transformation in an eutectoid steel, Scr. Mater., 39 (6), 791-796, 1998.

[17] G. F. Vander Voort, A. Roósz, Measurement of the interlamellar spacing of pearlite, Metallography, 17 (1), 1-17, 1984.

[18] O. Vázquez-Gómez, J.A. Barrera-Godínez, H.J. Vergara-hernández, Kinetic study of austenite formation during continuous heating of unalloyed ductile iron, International Journal of Minerals, Metallurgy and Materials, 22 (1), 27-31, 2015.

[19] C. L. Lopes, Study of the influence of microstructures on the kinetics of austenitization in the critical zone and mechanical properties of dual austempering ductile irons", Federal de Santa Catarina University, 2014.

[20] E. Akbarzadeh Chiniforush, N. Iranipour, S. Yazdani, Effect of nodule count and austempering heat treatment on segregation behavior of alloying elements in ductile cast iron, China Foundry, 13 (3), 217-222, 2016.

[21] ASTM 247-17, "Standard Test Method for Evaluating the Microstructure of Graphite in Iron Castings", 2018.

[22] ASTM 536-84," Standard Specification for Ductile Iron Castings", 2016.

[23] ASTM E112-13," Standard Test Methods for Determining Average Grain Size", 2016.

[24] H- Fredriksson and U. Åkerlind, Materials Processing during Casting. J. Wiley, 2006.

[25] C. G. De Andrés, F. G.Caballero, C. Capdevila, Dilatomometric study of the anisothermal decomposition of perlite in a low carbon steel, Rev. Metal-Madrid, 34 (c), 243-248, 1998.

[26] ASTM E562-19, "Standard Test Method for Determining Volume Fraction by Systematic Manual PointCount", 2011

[27] L. Nastac, D. Stefanescu. Modeling of Microsegregation in Ductile Iron, AFS Transactions, 101, 114, 1993.

[28] B. Y. Lin, E. T. Chen, and T. S. Lei, The Effect of Segregation on the Austemper Transformation and Toughness of Ductile Irons, Journal of Materials Engineering and Performance, 7, 407-419, 1998.

[29] F. G. Caballero, C. Capdevila, C. G. De Andrés, Mathematical Modeling of Iron and Steel Making Processes: Modelling of Kinetics of Austenite Formation in Steels with Different Initial Microstructures, ISIJ Int., 41 (10), 1093-1102, 2001.

[30] V. Gerval, J. Lacaze, Critical Temperature Range in Spheroidal Graphite Cast Irons. ISIJ Int., 40 (4), 356-392, 2000.

[31] C. G. De Andrés, F.G. Caballero, C. Capdevila, L. F. Álvarez, Application of dilatometric analysis to the study of solid-solid phase transformations in steels, Mater. Charact., 48 (1), 101-111, 2002.

[32] M. Hillertt, On the theory of normal and abnormal grain growth, Acta Metall., 13, 225-237, 1965.

[33] D.W. Suh, Dilatometric Analysis of Austenite Formation during Intercritical Annealing, Met. Mater. Int., 14 (3), 275-282, 2008. 